\title{
PENYELIDIKAN PERILAKU INTERAKSI KIMIAWI LAPISAN DIAMOND FILM PAHAT KARBIDA PADA OPERASI BUBUT KERING BAHAN Al 6061
}

\author{
Fransnazoan Sitorus \\ Teknik Mesin, Fakultas Teknik Universitas Asahan \\ E-mail: frans@una.ac.id frans.nazoanstr@yahoo.com \\ Hp: 08116330021,081370020021
}

\begin{abstract}
The purpose of the research was to characterize diamond-film coating which is used as carbide tool coating material, especially coating material (diamond-film CVD) and substrate material (WC/Co) in general approach interaction of chemically, This is related to the research which reported about the functional failure of carbide tool coating material, used in dry machinery process of non-ferro metal in the initial wear. The study on the characteristics of tool diamond-film coating was conducted through chemical interaction approaches which occurred between the working object and tool through dry machining process. Cutting condition was $v=350$ $\mathrm{m} / \mathrm{min} ; f=0.15 \mathrm{~mm} / \mathrm{put} ; \quad a=1.5 \mathrm{~mm}$ in Initial-wear phase $\left(t_{c}=1.736 \mathrm{~min}\right)$. The result of the test was abrasive wear $V_{B}=0.070 \mathrm{~mm}$. Chemical load was tested through micro analysis using energy dispersive analysis $X$-Ray spectroscopy (EDAX), the result of the test was the distribution of diamond-film coating elements in aluminum 6061 testing material on the cutting conditions indicated that diamond-film coating material was still significant. The conclusion of the study was that by using chemical interaction approaches, was no coating delamination in diamond-film coating of carbide tool. The phenomenon of the three approaches was the gradual disappearing of a part of the volume of diamond-film coating material which layered substrate material as the result of abrasivecoating wear.
\end{abstract}

Keywords: Diamond-Film Coatinge of CVD Carbide Tool, Chemical Interaction dan Abrasive-Coating Wear, Dry Machining

\begin{abstract}
Abstrak
Penelitian ini bertujuan untuk mengkarakterisasi lapisan diamond-film yang digunakan sebagai bahan pelapis pahat karbida khususnya bahan pelapis (diamond-film CVD) dan bahan substrate (WC/Co) pada umumnya through approach interaction of chemically, sehubungan dengan adanya laporan penelitian perihal kegagalan fungsi dari bahan pelapis pahat karbida yang digunakan pada proses pemesinan kering bahan non-ferro metal pada awal proses pemotongan berlangsung (initial wear). Kajian karakteristik lapisan diamond-film pahat dilakukan melalui pendekatan interaksi secara Kimiawi yang terjadi antara bahan benda kerja dan pahat melalui proses pemesinan kering. Kondisi pemotongan yaitu $\mathrm{v}=350 \mathrm{~m} / \mathrm{min} ; \mathrm{f}=0.15 \mathrm{~mm} / \mathrm{put} ; \mathrm{a}=1.5 \mathrm{~mm}$ pada fasa Initial-wear $\left(t_{c}=1.736 \mathrm{~min}\right)$. Hasil pengujian diperoleh keadaan Aus-abrasive $\mathrm{V}_{\mathrm{B}}=0.070 \mathrm{~mm}$. Uji interaksi kimiawi dilakukan melalui analisa mikro menggunakan energy dispersive analysis X-Ray spectroscopy (EDAX), hasil pengujian diperoleh sebaran unsur pelapis diamond-film pada bahan uji Aluminium 6061 terhadap kondisi pemotongan diperoleh keadaan unsur material pelapis diamond film masih signifikan. Dari hasil penelitian disimpulkan bahwa pendekatan interaksi secara kimiawi, tidak ditemukan peristiwa pengelupasan lapisan diamond-film pahat karbida, fenomena yang terjadi terhadap pendekatan yang dilakukan adalah peristiwa hilang bertahapnya sebagian volume material pelapis diamond-film yang melapisi material substrate akibat Aus pengikisan lapisan (abrasive-coating wear).
\end{abstract}

Kata kunci: Lapisan Diamond-film CVD Pahat Karbida, Interaksi Kimiawi dan Aus Pengikisan Lapisan, Dry Machining 


\section{Pendahuluan}

Pahat karbida mendominasi aplikasi modern pada industri pengerjaan logam dan menjadi pilihan terbaik untuk proses pemotongan logam. Pahat karbida telah terbukti menghasilkan kriteria hasil pemotongan terbaik terutama pada proses pemotongan bubut [1-2].

Seiring pesatnya perkembangan teknologi, maka untuk maksud meningkatkan performa serta resistensi aus pahat, pahat karbida dapat semakin ditingkatkan performanya melalui proses pelapisan. Pada teknologi pelapisan pahat tersebut, fungsi utama material pelapis adalah sebagai pelumas padat yang berfungsi untuk mereduksi gesekan dan panas tergenerasi selama proses pemotongan [3-4].

Pada teknologi pelapisan pahat pemotong tersebut, fungsi utama dari material pelapis adalah sebagai pelumas padat yang berfungsi untuk mereduksi gesekan dan panas tergenerasi selama proses pemotongan [5]. Dari kinerja tersebut jelas merupakan kerja dari bahan pelapis yang terbukti tangguh mereduksi pertumbuhan aus tepi, aus kawah dan aus yang diakibatkan oleh reaksi kimiawi antara benda kerja dan pahat. Banyak jenis metode proses rekayasa pelapisan pahat (coating), namun metode pelapisan yang paling berkembang saat ini adalah metode CVD (chemical vapour deposition) dan metode PVD (physical vapour deposition).

Untuk lebih mendapat informasi yang komprehensif tentang kinerja bahan pelapis pahat karbida yang banyak digunakan pada industri pemotongan logam khususnya untuk memproduksi produk-produk berbahan dasar aluminium, perlu dilakukan kajian terkait kinerja lapisan pahat karbida, hal tersebut sejalan dengan hasil penelitian [6], yang melaporkan bahwa performa bahan pelapis/lapisan pada pahat karbida berlapis tidak berfungsi sebagaimana yang diharapkan ketika digunakan pada operasi frais bahan non-ferro metal. Dalam laporannya menyimpulkan bahwa terjadi ragam aus yang baru dan dinamakan dengan pengelupasan pelapis (coating delamination). Hasil penelitian [6], mereka mendapati bahwa lapisanlapisan dari bahan pelapis yang digunakan untuk melapisi dari material inti (substrate) pahat karbida terkelupas pada saat proses pemotongan logam non-ferro berlangsung, mereka melaporkan secara rinci bahwa lapisan tersebut terkelupas pada saat awal proses pemotongan atau pada saat awal terjadinya aus (initial wear).

Pengelupasan lapisan (coating delamination) adalah mekanisme keausan pahat yang dapat disebabkan oleh beban Mekanik (impact), beban Thermal atau interaksi secara Kimiawi antara bahan benda kerja dan pahat. Pada proses aus ini, lapisan pahat yang menyelimuti bahan inti pahat (substrate) terkelupas akibat adanya tekanan/gaya potong atau thermal maupun reaksi kimia yang bekerja pada pahat yang melebihi kemampuannya (adhesiveforce) pada saat pemotongan. Jika pengelupasan terjadi, artinya lapisan pahat sama sekali tidak memiliki fungsi, maka ekspektasi penggunaan bahan pelapis pada pahat yang dimaksudkan untuk meningkatkan performa pahat dan meningkatkan produktivitas serta laju pemesinan tidak terwujud.

Objek yang dikaji pada penelitian dengan topik pemesinan kering, subjek pada penelitian ini konsentrasikan pada kajian karakteristik lapisan diamond-film pahat karbida ketika digunakan untuk memotong benda kerja Aluminium paduan 6061 (non-fero metal) pada metode pemesinan kering melalui operasi bubut. Pada penelitian ini kajian karakteristik mekanisme keausan mata pahat dilakukan melalui pendekatan interaksi secara Kimiawi yang terjadi antara bahan benda kerja dan pahat.

Penelitian ini bertujuan untuk mengkarakterisasi lapisan film diamond yang digunakan sebagai bahan pelapis pahat karbida dari dan interaksi kimiawi antar bahan benda kerja dan bahan pahat, khususya bahan pelapis (diamond film) dan bahan substrat (WC/Co) pahat karbida pada umumnya.

Hasil penelitian ini diharapkan dapat memberi manfaat bagi dunia akademik dan industri pemotongan logam pada umumnya serta bagi peneliti pada khususnya, adapun manfaat tersebut adalah guna memberi kontribusi pada penyediaan data dan informasi perencanaan proses bubut kering bahan non ferro metal, khususnya informasi karakteristik lapisan diamond-film yang digunakan sebagai bahan pelapis pahat.

\section{Studi Literatur}

\section{Pemesinan Kering}

Pada konsep pemesinan kering cairan pemotong tidak lagi digunakan dalam jumlah yang besar bahkan jika mungkin ditiadakan sama sekali [3]. Usaha untuk mengurangi penggunaan cairan pemotongan (cutting fluid) pada proses pemotongan logam terus dilakukan berdasar pada ekologi, kesehatan dan ekonomi [9].

Fenomena kegagalan pahat serta penggunaan cairan pemotongan pada pengerjaan pemotongan logam adalah masalah yang telah banyak mendapat perhatian untuk dikaji, karena dalam kaitannya sangat berpengaruh terhadap kekasaran permukaan, geometri, mekanisme aus serta umur pahat hasil pemesinan [9].

\section{Karakteristik Terminologi Proses Bubut}

Membubut merupakan salah satu operasi pemesinan yang paling umum dan banyak ditemui pada industri pemotongan logam. Pada proses ini benda kerja yang dicekam pada chuck berotasi pada 
sumbunya, sedang pahat sebagai alat potong bergerak translasi menyayat benda kerja sepanjang sumbu benda kerja atau terhadap diameternya. skematis dari sebuah proses bubut dimana putaran poros utama (n), pemakanan (f) dan kedalaman potong (a), seperti terlihat pada gambar 1 .

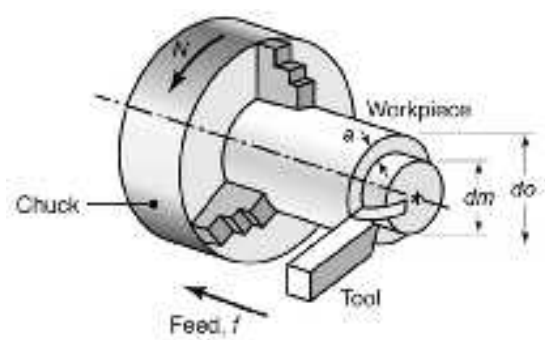

Sumber: Kalpakjian and Schmid, (2006)

Gambar 1. Skematis Proses Bubut

Elemen dasar pada proses bubut diketahui berdasarkan Gambar 2 berikut ini :

1. Kecepatan potong (cutting speed): $v(\mathrm{~m} / \mathrm{min})$

2. Kecepatan makan (feeding speed): $V f(\mathrm{~mm} / \mathrm{min})$

3. Kedalaman potong (depth of cut): $a(\mathrm{~mm})$

4. Waktu pemotongan (cutting time): $t_{c}(\mathrm{~min})$

5. Laju pembuangan geram (material removal rate): $\mathrm{Z}(\mathrm{cm} 3 / \mathrm{min})$.

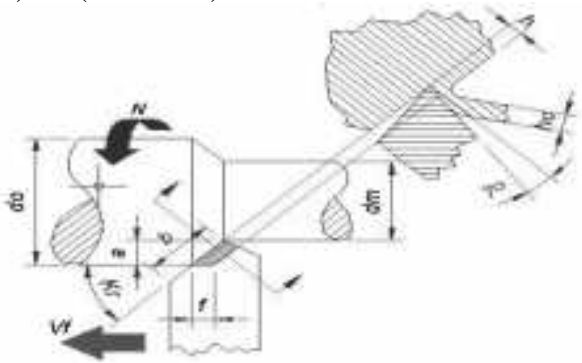

Sumber: Kalpakjian, (2003).

Gambar 2. Proses Bubut

Geometri benda kerja:

$d o=$ diameter awal $(\mathrm{mm})$

$d m=$ diameter akhir $(\mathrm{mm})$

$l t=$ panjang pemesinan $(\mathrm{mm})$

Geometri pahat:

$k r$ = sudut potong utama (o)

$\gamma_{0}=$ sudut geram (o)

Kondisi pemesinan

$a=$ kedalaman potong

$a=\frac{a-a}{2}(\mathrm{~mm})$

$f=$ pemakanan $(\mathrm{mm} /$ putaran $)$

$N=$ putaran poros utama (rpm)

Dengan diketahuinya besaran-besaran diatas, sehingga kondisi pemotongan dapat diperoleh sebagai berikut:

Laju pemotongan

$v=\frac{\pi \cdot d \cdot n}{1}$

Dimana

$d=$ diameter rata-rata $d=\frac{a+d}{2}(\mathrm{~mm})$

Laju pemakanan

$v f=f . N(\mathrm{~mm} / \mathrm{min})$

Waktu pemotongan

$t c=\frac{u}{V}(\mathrm{~min})$

\section{Bahan Pahat}

Prinsip dasar pemesinan adalah kemampuan ketangguhan (toughness) pahat terhadap benda kerja. Banyak perkembangan pada bahan pahat guna untuk semakin meningkatkan kemampumesinan, dimana geometri dan bahan pahat merupakan hal yang perlu di pertimbangkan. Syarat bahan pahat yang harus dipenuhi mencakup: kekerasan, ketangguhan, rendah sifat adhesi, rendah penyerapan dan tahan aus.

\section{Pelapisan Pahat}

Salah satu fungsi utama dari lapisan (coated) adalah untuk meningkatkan kinerja dari pahat tersebut [5]. Tingkat pelapisan pahat karbida yaitu single layer, two layer dan multilayer [13]. Banyak jenis metode proses rekayasa pelapisan (coating) permukaan bahan yang bertujuan untuk menambah kekerasan, tahan korosi dan tahan terhadap keausan [17], diantaranya metoda evavorasi, chemical vapour deposition (CVD), physical vapour deposition (PVD), karburasi, nitridasi, implantasi ion, industri listrik dan sputtering, tipe Pelapisan Film Diamond CVD dapat dilihat pada Gambar 3.

Metode CVD menghasilkan ikatan yang lebih kuat dibanding dengan metode PVD [13]. Pada metode CVD, beberapa jenis gas bereaksi sehingga menghasilkan padatan yang kemudian terdeposisi diatas substrate. Reaksi kimia dalam deposisi CVD dapat diungkapkan seperti persamaan $\mathrm{AB}_{\text {gas }}+\mathrm{CD}_{\text {gas }}$ $\leftrightarrow \mathrm{AC}_{\text {padatan }}+\mathrm{BD}_{\text {gas }}$, terjadinya reaksi kimia yang merupakan ciri metode CVD [18]. Dalam proses ini reaksi berlangsung pada suhu tinggi. Padatan (film) yang dihasilkan terdeposisi diatas substrate yang dipanaskan.

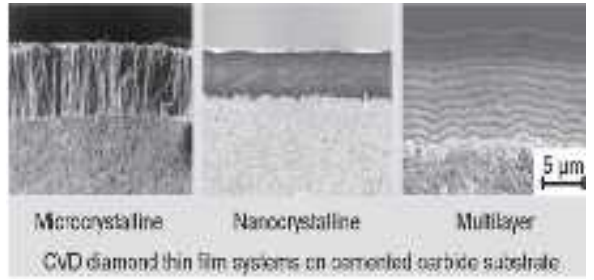

Sumber: E. Uhlmann (1)*, J. Koenig, (2009).

Gambar 3. Tipe Pelapisan Film Diamond CVD

\section{Karakteristik Kegagalan Pahat}

Efek kegagalan pahat ditinjau dari performa secara teknik yaitu berkaitan dengan konsekuensi menurunnya akurasi dimensi, meningkatnya kekasaran permukaan, meningkatnya suhu 
pemotongan, besarnya gaya potong, getaran yang meningkat, menurunnya effisiensi produksi dan meningkatnya ongkos produksi. Karakteristik kegagalan pahat dan mekanismenya dapat menyebabkan umur pahat berakhir lebih cepat (premature end), pada Gambar 4. berikut dapat dilihat ragam bentuk kegagalan pahat.

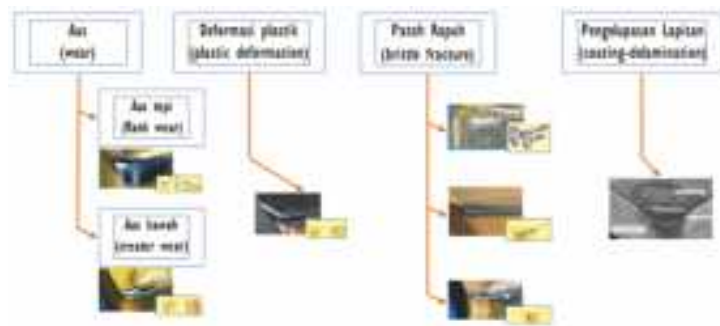

Sumber: ISO 3685 (1993); J. Hu, et.al, (2008)

Gambar 4. Ragam bentuk kegagalan pahat

1. Aus (wear)

Aus (wear) di karakteristikan:

a. Aus Tepi (flank wear)

b. Aus Kawah (crater wear)

2. Deformasi Plastik (plastic deformation)

3. Patah Rapuh (brittle fracture)

Patah rapuh pahat diklasifikasikan atas:

a. Penyerpihan (chipping):

b. Aus takikan (notch wear):

c. Retak (cracking):

d. Aus ujung pahat (nose wear):

Kriteria kegagalan adalah apabila terjadi Aus tepi (VB) dan berulang pada kecepatan potong yang berbeda terhadap fungsi waktu, Batas keausan tepi pahat adalah $0.3 \mathrm{~mm}$ pada waktu pemotongan tidak kurang dari 5 menit [18], pada Gambar 5. menjelaskan besar pertumbuhan Aus tepi $\left(\mathrm{V}_{\mathrm{B}}\right)$ berulang terhadap fungsi waktu.

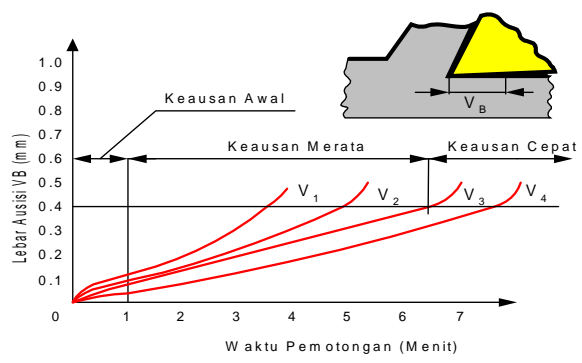

Sumber: Boothroyd \& Kinght 1989

Gambar 5.Kurva kedalaman aus sisberulang terhadap fungsi waktu

\section{Pengelupasan Lapisan (coating delamination)}

Pengelupasan lapisan (coating delamination) merupakan kejadian hilangnya bagian pahat dalam bentuk lapisan dari permukaan pahat. Secara substantif dinyatakan bahwa adalah peristiwa kepindahan lokal atau pealing material untuk membuka substrate pahat, bentuk pengelupasan pelapis pada Gambar 6.

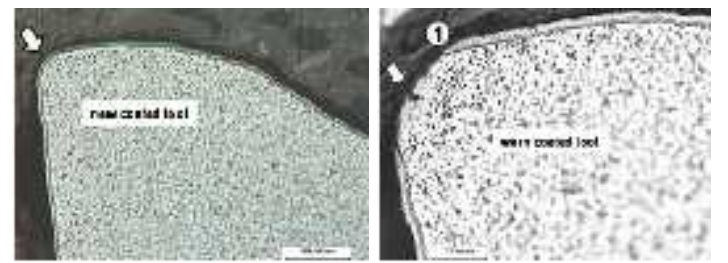

Sumber: Nouari dan Ginting, (2006).

Gambar 6. Pengelupasan Lapisan

\section{Metode}

Bahan

Penelitian ini menggunakan bahan uji Aluminium $6061 \mathrm{AlMg} 1 \mathrm{SiCu}$, berbentuk billet, dengan panjang $220 \mathrm{~mm}$ dan diameter $132 \mathrm{~mm}$. Material ini dipilih karena material ini sangat aplikatif dan biasa terdapat pada: perangkatperangkat penerbangan, armada laut, piston, piston rem serta aplikasi lainnya [15]. Benda kerja terdapat pada Gambar 7. Komposisi kimia dan kekerasan material ini dapat dilihat sebagaimana tertera pada Tabel 1. dan Tabel 2. berikut ini.

Tabel 1. Komposisi kimia bahan $\mathrm{Al} 6061 \mathrm{AlMg} 1 \mathrm{SiCu}$

\begin{tabular}{|c|c|c|c|c|c|c|c|c|c|c|}
\hline $\begin{array}{l}\text { Al } \\
(\%)\end{array}$ & $\underset{(\%)}{\mathbf{S i}}$ & $\begin{array}{c}\mathrm{Fe} \\
(\%)\end{array}$ & $\begin{array}{l}\mathrm{Cu} \\
\%)\end{array}$ & $\underset{(\%)}{\text { Mn }}$ & $\begin{array}{l}\mathrm{Mg} \\
(\%)\end{array}$ & $\begin{array}{l}\mathrm{Zn} \\
(\%)\end{array}$ & $\underset{(\%)}{\mathbf{C r}}$ & $\begin{array}{l}\mathrm{Ni} \\
\%)\end{array}$ & $\begin{array}{c}\mathbf{T i} \\
(\%)\end{array}$ & $\begin{array}{c}\mathrm{Ca} \\
(\%)\end{array}$ \\
\hline 98.1 & 0.577 & 0.001 & 0.163 & 0.034 & 0.929 & 0.050 & 0.089 & 0.002 & 0.011 & 0.004 \\
\hline $\begin{array}{c}\mathrm{Pb} \\
(\%)\end{array}$ & $\begin{array}{l}\text { Sn } \\
(\%)\end{array}$ & $\underset{(\%)}{\mathbf{V}}$ & $\begin{array}{l}\mathbf{B i} \\
\%)\end{array}$ & $\begin{array}{c}\mathbf{Z r} \\
\text { ) }\end{array}$ & $\begin{array}{l}\text { Ga } \\
(\%)\end{array}$ & $\begin{array}{c}\text { Co } \\
(\%)\end{array}$ & $\underset{(\%)}{\mathbf{H g}}$ & $\begin{array}{l}\text { In } \\
\%)\end{array}$ & $\begin{array}{l}\text { Sb } \\
(\%)\end{array}$ & $\begin{array}{c}\text { La } \\
(\%)\end{array}$ \\
\hline 0.001 & 0.002 & 0.009 & 0.003 & 0.001 & 0.007 & 0.002 & 0.002 & 0.003 & 0.010 & 0.001 \\
\hline
\end{tabular}

Sumber: Lab. Pengujian Bahan, Unimed. (2014).

Tabel 2. Kekerasan bahan $\mathrm{Al} 6061 \mathrm{AlMg} 1 \mathrm{SiCu}$

\begin{tabular}{ccccc}
\hline Material & $\begin{array}{c}\text { Test } \\
\text { I }\end{array}$ & $\begin{array}{c}\text { Test } \\
\text { II }\end{array}$ & $\begin{array}{c}\text { Test } \\
\text { III }\end{array}$ & HRB \\
\hline $\begin{array}{c}\text { Aluminium } 6061 \\
\text { AlMg1SiCu }\end{array}$ & 53.0 & 53.5 & 53.0 & 53.3 \\
\hline
\end{tabular}

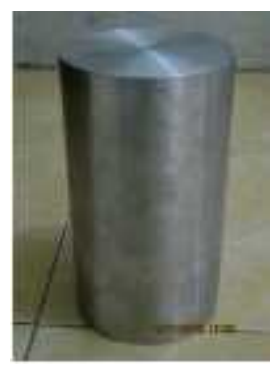

Gambar 7. Bahan benda uji Al 6061

\section{Pahat potong}

Pahat pemotong yang digunakan pada penelitian ini yaitu jenis karbida berlapis diamond film (single layer). Menurut berpengenal standard ISO klasifikasi N10 maka pahat ini digunakan untuk bahan non ferro metal. Bentuk dan ukuran sesuai 
standar ISO yaitu DCGX 11 T3 04-AL 1810. spesifikasi taknis dapat dilihat pada Tabel 3. dan Gambar 8, berikut ini.

Tabel 3. Sifat pahat karbida ISO-N10 DCGX 11 T3 04AL 1810

\begin{tabular}{|c|c|c|c|c|c|c|c|}
\hline \multicolumn{5}{|c|}{ Komposisi } & \multicolumn{3}{|c|}{$\begin{array}{l}94 \% \mathrm{WC} \\
6 \% \mathrm{Co}\end{array}$} \\
\hline $\begin{array}{c}\text { Coating } \\
\text { Thickness } \\
(\mu \mathrm{m})\end{array}$ & $\underset{\text { Size }(\mu \mathrm{m})}{\operatorname{Grain} 1}$ & $\begin{array}{l}\text { Hardness } \\
(\mathrm{HV})\end{array}$ & $\begin{array}{c}\text { Coating } \\
\text { Spesification }\end{array}$ & $\begin{array}{c}\text { Radius } \\
\text { Nose } \\
(\mathrm{mm})\end{array}$ & $\begin{array}{c}\text { Max Dept } \\
\text { of Cut } \\
(\mathbf{m m})\end{array}$ & $\begin{array}{c}\text { Max Cutting } \\
\text { Speed } \\
(\mathbf{V}=\mathrm{m} / \mathrm{min})\end{array}$ & $\begin{array}{c}\text { Max } \\
\text { Feeding } \\
(\mathbf{m m})\end{array}$ \\
\hline 6.0 & $1.4-2.5$ & 1710 & $\begin{array}{c}\text { Diamond-film } \\
\text { CVD }\end{array}$ & 0.4 & 1.5 & 2000 & 0.2 \\
\hline
\end{tabular}
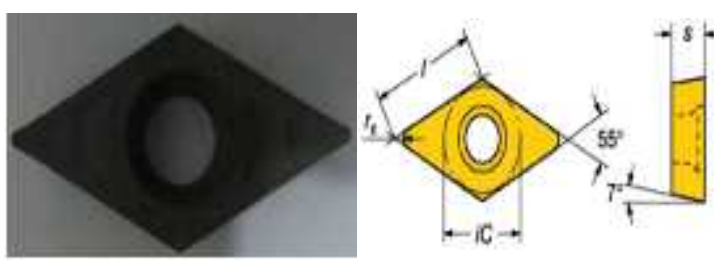

Sumber: Sandvik Corromant, (2012).

Gambar 8. Pahat dan Geoetri ISO-N10 DCGX 11 T3 04 AL 1810

Pemegang pahat (tool-holder)

Pemegang pahat yang digunakan adalah jenis SDJC R-S 2020K $11\left(93^{\circ}\right)$ yang dikhususkan untuk proses bubut dan dapat dilihat pada gambar 9 .
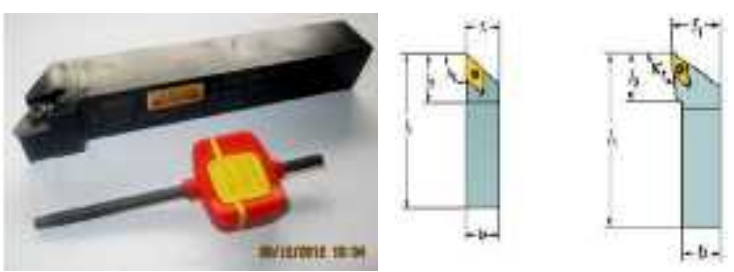

Gambar 9. Pemegang pahat dan Geometri jenis SDJC RS 2020K 11

Alat

Portable dan Rockwell hardness tester

Untuk mengetahui nilai kekerasan bahan uji, benda uji diperiksa terlebih dahulu menggunakan Portable hardness tester yang kemudian pengujian dibandingkan dengan hasil pengukuran kekerasan menggunakan Rockwell hardness tester untuk mendapatkan validasi data, spesifikasi data teknis dan pemeriksaan kekerasan benda uji dapat dilihat pada Gambar 10.
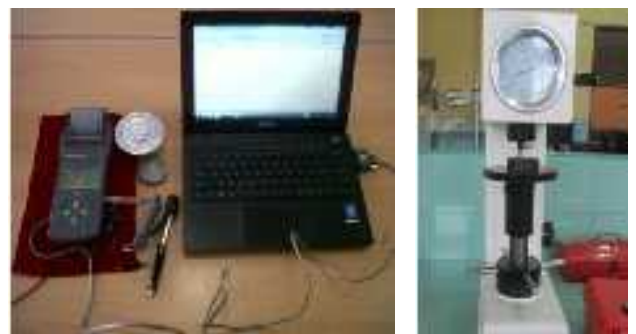

Gambar 10. Portable hardness test TH160 dan Rockwell hardness test TH500

Foundry Master

Untuk mengetahui prosesntase besaran kandungan unsur pada bahan uji, dilakukan pengujian komposisi menggunakan mesin Foundry Master, seperti yang terlihat pada gambar 11 . berikut ini
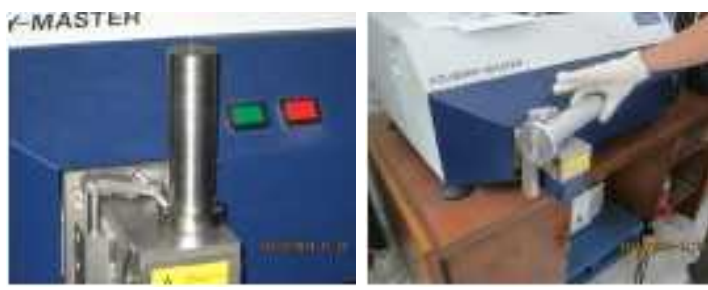

Gambar 11. Pemeriksaan data komposisi benda uji

\section{Mesin Bubut}

Pemesinan dilakukan menggunakan mesin bubut CD 6260-C, spesifikasi data teknis sebagaimana dilihat pada Gambar 12 berikut.

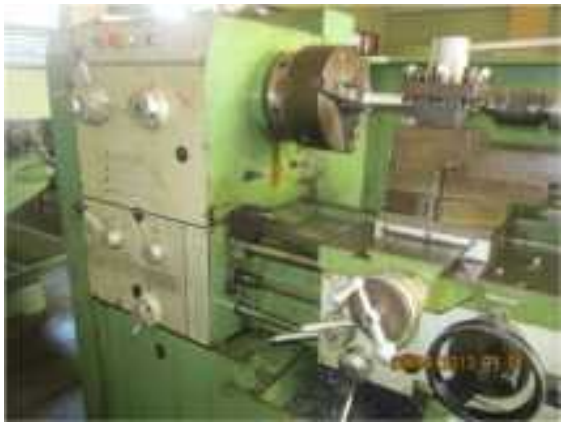

Gambar 12. Mesin bubut CD 6260-C

\section{USB Digital Microscope}

Untuk mengambil data gambar keausan awal pahat yang terjadi setelah proses pemesinan digunakan USB Digital Microscope Cameras, lensa dual Axis $27 \mathrm{x} / \mathrm{WO}=8 \mathrm{~mm}$ dan $100 \mathrm{x} / \mathrm{WO}=2 \mathrm{~mm}$ micro-scope le lense. USB digital microscope dapat dilihat pada, Gambar 13. berikut ini.

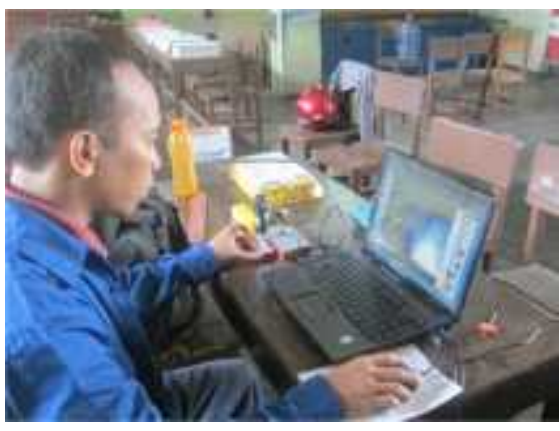

Gambar 13. USB digital microscope

Scanning Electron Microscope (SEM)-Energy Dispersive Spectroscopy (EDS) 
Scanning electron microscope (SEM), electron microscope mempunyai perbesaran sampai 20 ribu kali, elektron digunakan sebagai pengganti cahaya. SEM digunakan untuk studi detail arsitektur permukaan sel (struktur renik lainnya), obyek diamati secara tiga dimensi. Topografi pahat maupun mikrostrukturnya dan untuk menganalisa permukaan dan tekstur (kekerasan, reflektivitas) termasuk morfologi dan komposisi digunakan energy dispersive spectroscopy (EDS). Peralatan SEM-EDS serta spesifikasi dari peralatan scanning electron microscope (SEM) merk HITACHI dengan Tipe BSE Compo adalah sebagai berikut: dapat dilihat pada Gambar 14. berikut ini.

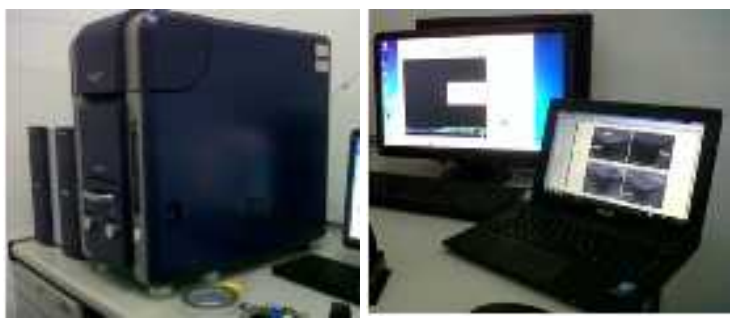

Gambar 14. Scanning electron microscopy (SEM-EDS) TM-3000

\section{Rancangan Kegiatan Penelitian}

\section{Setup Pemesinan}

1. Menyiapkan peralatan pengambilan data diantaranya:

a. Mesin bubut konvensional CD 6260-C serta menyiapkan pahat insert karbida un-coated dan berlapis diamond-film.

b. Pemegang pahat/tool holder.

c. Bahan uji Al 6061.

d. USB digital mikroskop.

2. Memeriksa kondisi mesin yang harus benarbenar kaku dan tidak speeling.

3. Menyesuaikan diameter benda uji pada putaran mesin (rpm) mesin bubut CD 6260-C.

4. Memulai langkah pemesinan dengan menentukan putaran mesin (rpm), pemakanan (f) dan kedalaman potong (a).

5. Menjalankan mesin sesuai kondisi pemotongan.

6. Mengambil data awal mode aus dengan USB digital microscope dengan cara sbb:

a. Setelah pemesinan dilakukan dengan panjang pemesinan (lt) sesuai dengan benda kerja maka pahat diletakkan diatas plestisin.

b. Mengatur focus sampai gambar keausan pahat terlihat jelas.

c. Capture gambar buka di file desktop.

Uji Pengaruh Reaksi Kimiawi

1. Mekanisme Pengujian Reaksi Kimiawi

2

Pengujian pada aspek pengaruh akibat adanya reaksi kimia yang mengakibatkan terjadinya kegagalan pahat berupa pengelupasan pelapis/lapisan pada pahat, maka untuk menganalisa digunakan scanning electron microscope (SEM) dan energy dispersive spectroscopy (EDS). Sebagai langkah awal, pahat hasil pemesinan difoto terlebih dahulu SEM dengan tujuan untuk mengetahui mode dan besaran kegagalan pahat yang terjadi dan menentukan titik analisa spectrum yang akan dianalisa, kemudian dilanjutkan menggunakan energy dispersive analysis by X-Ray spectroscopy (EDAX) dengan tujuan untuk mengetahui sebaran unsur pada titik spectrum analisis.

\section{Metode Analisa Reaksi Kimiawi}

Analisa mekanisme terjadinya kegagalan pahat berupa pengelupasan lapisan/pelapis berdasarkan hasil analisis mikro menggunakan SEM dan X-Ray/EDAX. Pembuktian melalui analisa X-Ray/EDAX dapat membuktikan tentang adanya pengaruh reaksi kimiawi yang terjadi sebagai penyebap kegagalan fungsi lapisan pahat karbida berlapis diamond-film.

\section{Diagram Alir Penelitian}

Tahapan-tahapan proses penelitian ini digambarkan kedalam diagram alir penelitian diperlihatkan pada Gambar 15.

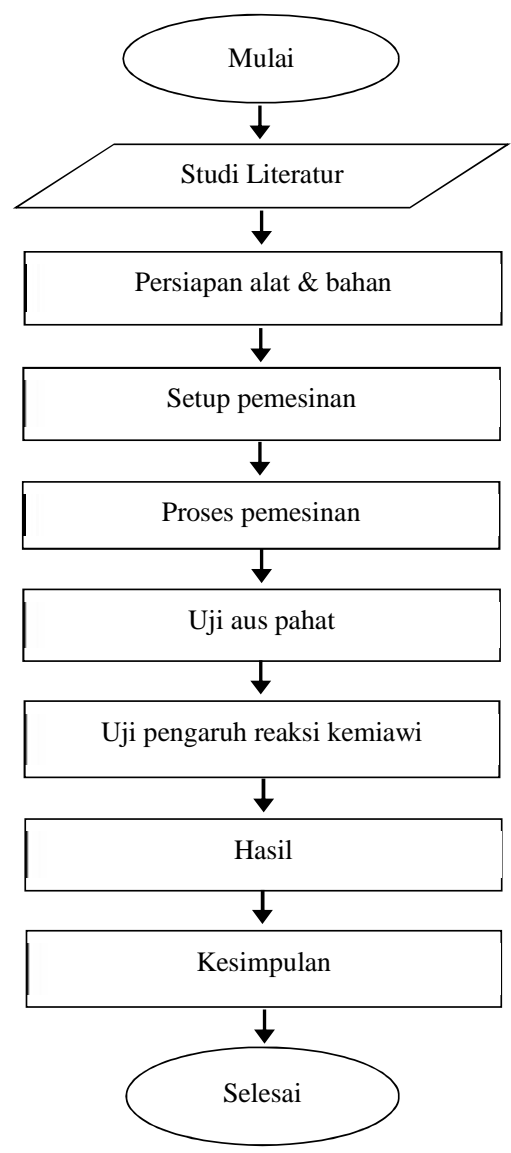


Gambar 15. Diagram alir penelitian

\section{Hasil dan Pembahasan}

\section{Pahat Karbida Un-coated}

Adapun hasil uji pahat karbida un-coated pemesinan bahan uji $\mathrm{Al} 6061$ adalah sebagai berikut.

Tabel 4. Hasil uji pahat karbida un-coated pemesinan bahan uji Al 6061

\begin{tabular}{cccccccc}
\hline $\begin{array}{c}\mathbf{v} \\
(\mathbf{m} / \mathbf{m i n})\end{array}$ & $\begin{array}{c}\mathbf{f} \\
(\mathbf{m m} / \mathbf{p u t})\end{array}$ & $\begin{array}{c}\mathbf{a} \\
(\mathbf{m m})\end{array}$ & $\begin{array}{c}\mathbf{d} \\
(\mathbf{m m})\end{array}$ & $\begin{array}{c}\mathbf{n} \\
(\mathbf{r p m})\end{array}$ & $\begin{array}{c}\mathbf{I t} \\
(\mathbf{m m})\end{array}$ & $\begin{array}{c}\mathbf{t}_{\mathbf{c}} \\
(\mathbf{m i n})\end{array}$ & $\begin{array}{c}\mathbf{V B} \\
(\mathbf{m m})\end{array}$ \\
\hline 350 & 0.15 & 1.5 & 132 & 845 & 55 & 0.434 & 0.000 \\
350 & 0.15 & 1.5 & 132 & 845 & 110 & 0.868 & 0.020 \\
350 & 0.15 & 1.5 & 132 & 845 & 165 & 1.302 & 0.030 \\
350 & 0.15 & 1.5 & 132 & 845 & 220 & 1.736 & 0.050 \\
350 & 0.15 & 1.5 & 132 & 845 & 275 & 2.170 & 0.060 \\
350 & 0.15 & 1.5 & 132 & 845 & 330 & 2.604 & 0.070 \\
350 & 0.15 & 1.5 & 132 & 845 & 385 & 3.037 & 0.073 \\
350 & 0.15 & 1.5 & 132 & 845 & 440 & 3.471 & 0.079 \\
350 & 0.15 & 1.5 & 132 & 845 & 495 & 3.905 & 0.086 \\
350 & 0.15 & 1.5 & 132 & 845 & 550 & 4.339 & 0.088 \\
350 & 0.15 & 1.5 & 132 & 845 & 605 & 4.773 & 0.091 \\
350 & 0.15 & 1.5 & 132 & 845 & 660 & 5.207 & 0.100 \\
\hline
\end{tabular}

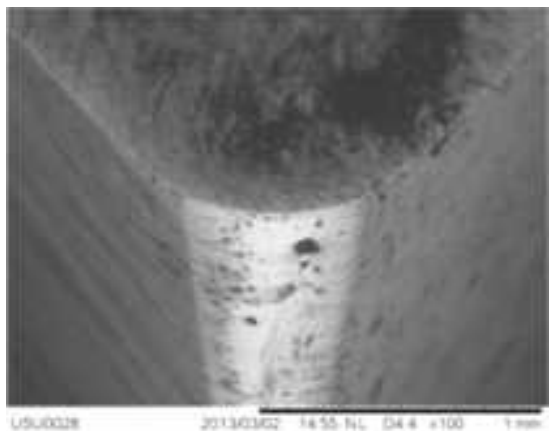

Gambar 16. Penampang pahat karbida un-coated original

Pahat karbida un-coated original dengan komposisi material inti (substrate) yaitu: $\mathrm{WC}=94$ $\%$ dan $\mathrm{Co}=6 \%$. Pahat karbida un-coated didesain khusus untuk pemesinan bubut dengan data rekomendasi pemotongan yaitu mampu melakukan pemotongan kecepatan (v) hingga $2000 \mathrm{~m} / \mathrm{min}$ dengan kedalaman potong (a) hingga $1.5 \mathrm{~mm}$ dan pemakanan (f) hingga $0.20 \mathrm{~mm} /$ put.

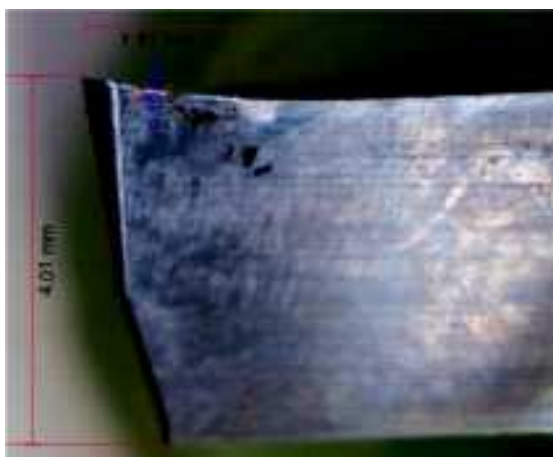

Gambar 17.Aus tepi pahat karbida un-coated, bahan uji Al 6061, kondisi: $\mathrm{v}=350 \mathrm{~m} / \mathrm{min} \mid \mathrm{t}_{\mathrm{c}}=5.207$ $\min \mid \mathrm{V}_{\mathrm{B}}=0.100 \mathrm{~mm}$.

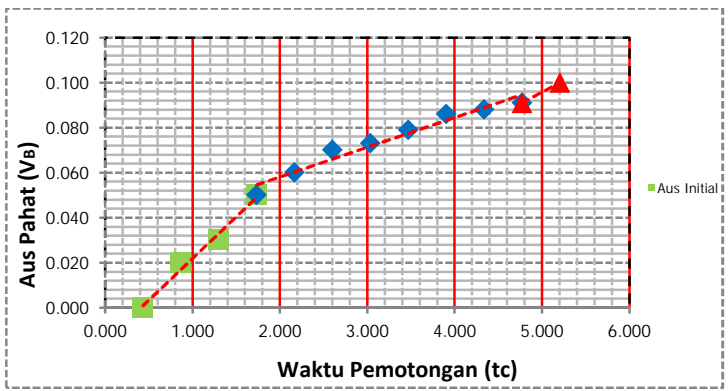

Gambar 18.Kurva 3 fasa pertumbuhan Aus tepi, bahan Al 6061 Kondisi: $v=350 \mathrm{~m} / \mathrm{min} ; \mathrm{f}=0.15$ $\mathrm{mm} / \mathrm{rad} ; \mathrm{a}=1.5 \mathrm{~mm}$.

Gambar 17 dan Gambar 18 pada pemesinan bahan uji Al 6061, menjelaskan keausan pahat dan kurva 3 fasa laju pertumbuhan Aus tepi, Terhadap hasil pengukuran Aus tepi pahat ditetapkan masih dalam batas toleransi Aus pahat yaitu: $\mathrm{V}_{\mathrm{B}}>0.3 \mathrm{~mm}$ (dibawah $\mathrm{V}_{\mathrm{Bmax}}$ ) dalam waktu pemotongan tidak kurang 5 min, [18].

\section{Pahat Karbida Berlapis Diamond-Film}

Hasil uji pahat karbida karbida berlapis diamond-film pemesinan bahan $\mathrm{Al} 6061$ adalah sebagai berikut.

Tabel 5. Hasil uji pahat karbida berlapis diamond-film pemesinan bahan $\mathrm{Al} 606$

\begin{tabular}{cccccccc}
\hline $\begin{array}{c}\mathbf{v} \\
(\mathbf{m} / \mathbf{m i n})\end{array}$ & $\begin{array}{c}\mathbf{f} \\
(\mathbf{m m} / \mathbf{p u t})\end{array}$ & $\begin{array}{c}\mathbf{a} \\
(\mathbf{m m})\end{array}$ & $\begin{array}{c}\mathbf{d} \\
(\mathbf{m m})\end{array}$ & $\begin{array}{c}\mathbf{n} \\
(\mathbf{r p m})\end{array}$ & $\begin{array}{c}\mathbf{I t} \\
(\mathbf{m m})\end{array}$ & $\begin{array}{c}\mathbf{t}_{\mathbf{c}} \\
(\mathbf{m i n})\end{array}$ & $\begin{array}{c}\mathbf{V B} \\
(\mathbf{m m})\end{array}$ \\
\hline 350 & 0.15 & 1.5 & 132 & 845 & 55 & 0.434 & 0.000 \\
350 & 0.15 & 1.5 & 132 & 845 & 110 & 0.868 & 0.035 \\
350 & 0.15 & 1.5 & 132 & 845 & 165 & 1.302 & 0.051 \\
350 & 0.15 & 1.5 & 132 & 845 & 220 & 1.736 & 0.096 \\
350 & 0.15 & 1.5 & 132 & 845 & 275 & 2.170 & 0.164 \\
350 & 0.15 & 1.5 & 132 & 845 & 330 & 2.604 & 0.194 \\
350 & 0.15 & 1.5 & 132 & 845 & 385 & 3.037 & 0.229 \\
350 & 0.15 & 1.5 & 132 & 845 & 440 & 3.471 & 0.254 \\
350 & 0.15 & 1.5 & 132 & 845 & 495 & 3.905 & 0.269 \\
350 & 0.15 & 1.5 & 132 & 845 & 550 & 4.339 & 0.284 \\
350 & 0.15 & 1.5 & 132 & 845 & 605 & 4.773 & 0.313 \\
350 & 0.15 & 1.5 & 132 & 845 & 660 & 5.207 & 0.420 \\
\hline
\end{tabular}

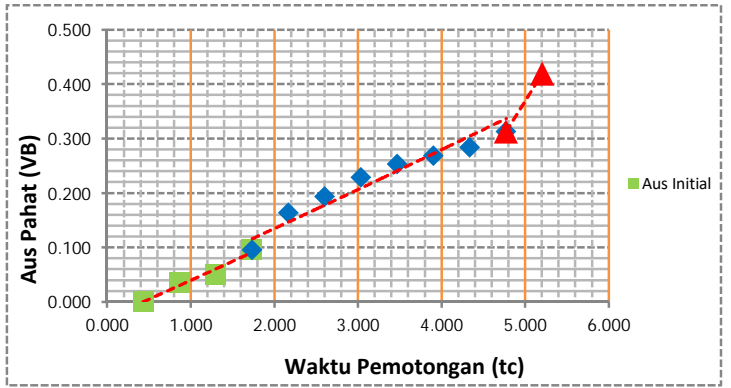

Gambar 19.Kurva pertumbuhan Aus tepi pahat,bahan uji Al 6061 Kondisi: $v=350 \mathrm{~m} / \mathrm{min} ; \mathrm{f}=0.15$ $\mathrm{mm} / \mathrm{rad} ; \mathrm{a}=1.5 \mathrm{~mm} ; \mathrm{t}_{\mathrm{c}}=5.207$ min dan $\mathrm{V}_{\mathrm{B}}=$ $0.420 \mathrm{~mm}$

Tabel 6. Hasil uji pahat berlapis diamond film, bahan uji Al 6061 fasa Initial-wear 


\begin{tabular}{|c|c|c|c|c|c|c|c|}
\hline $\begin{array}{c}\mathbf{v} \\
(\mathbf{m} / \mathbf{m i n})\end{array}$ & $\begin{array}{c}\mathbf{f} \\
(\mathrm{mm} / \text { put })\end{array}$ & $\underset{(\mathrm{mm})}{\mathrm{a}}$ & $\underset{(\mathbf{m m})}{\mathbf{d}}$ & $\underset{(\mathbf{r p m})}{\mathbf{n}}$ & $\underset{(\mathbf{m m})}{\mathbf{I t}}$ & $\begin{array}{c}\mathbf{t}_{\mathrm{c}} \\
(\mathbf{m i n})\end{array}$ & $\begin{array}{c}\text { VB } \\
(\mathbf{m m})\end{array}$ \\
\hline 350 & 0.15 & 1.5 & 132 & 845 & 220 & 1.736 & 0.070 \\
\hline
\end{tabular}

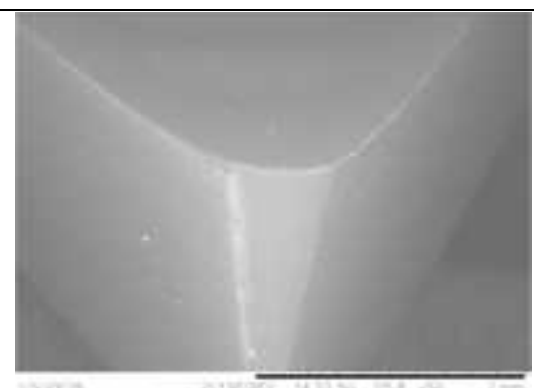

Gambar 20.Pahat karbida berlapis diamond film original.

Gambar 20, adalah pahat karbida berlapis diamond film original dengan komposisi material inti (substrate) $\mathrm{WC}=94 \%$ dan $\mathrm{Co}=6 \%$ dan material pelapis tungggal diamond-film single layer $(6 \mu \mathrm{m})$.

Pahat ini di desain khusus untuk pemesinan bubut dengan data rekomendasi pemotongan yaitu mampu melakukan pemotongan kecepatan (V) hingga $2000 \mathrm{~m} / \mathrm{min}$ dengan kedalaman potong (a) hingga $1.5 \mathrm{~mm}$ dan pemakanan (f) hingga 0.20 $\mathrm{mm} / \mathrm{put}$

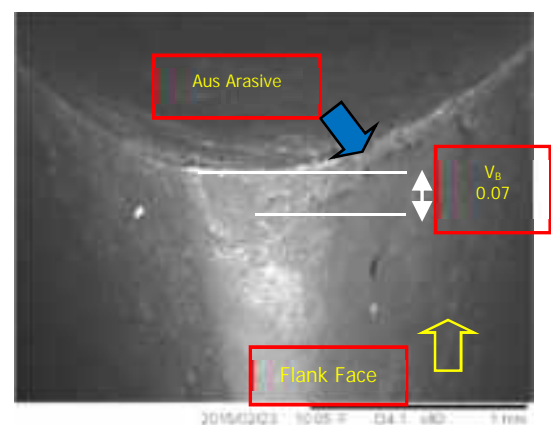

Gambar 21. Aus abrasive (initial-wear) pahat karbida berlapis diamond film bahan uji $\mathrm{Al} 6061$. Kondisi: $v=350 \quad \mathrm{~m} / \mathrm{min} \mid \mathrm{t}_{\mathrm{c}}=1.736 \mathrm{~min}$; $104.160 \mathrm{dtk} \mid \mathrm{V}_{\mathrm{B}}=0.070 \mathrm{~mm} ; \mathrm{V}_{\mathrm{B}}{ }^{\circ}=0.000672$ $\mathrm{mm} / \mathrm{dtk}$.

Sebagaimana diperlihatkan pada Gambar 21, besar pertumbuhan Aus pada tepi yaitu: $V_{B}=0.070$ $\mathrm{mm}$ dengan percepatan aus rata-rata $\mathrm{V}_{\mathrm{B}}{ }^{\circ}=0.000672$ $\mathrm{mm} / \mathrm{dtk}$ yang terjadi terhadap pahat pada fasa Initial-wear $t_{c}=1.736$ min. Secara rinci bentuk kegagalan yang terjadi pada mata potong pahat ditetapkan sebagai Aus pengikisan (abrasive-wear), dimana besaran Aus pengikisan diukur dari puncak muka sadak mata pahat (rake face) terhadap batas bawah terjadinya Aus (wear).

Terhadap besar Aus abrasive yang terjadi masih dalam batas dibawah $\mathrm{V}_{\mathrm{B}} \max \left(\mathrm{V}_{\mathrm{B}}>0.3 \mathrm{~mm}\right)$. Maka hasil penelitian terhadap pengaruh beban mekanik dapat diartikan bahwasanya pada penggunaan bahan uji Al 6061 (non-ferro metal) mengindikasikan bahwa keadaan yaitu tidak dijumpai kegagalan pahat dalam wujud pengelupas lapisan/pelapis pahat terhadap material substrate.

\section{Uji Pengaruh Reaksi Kimiawi}

Analisa lapisan diamond-film pahat bahan uji Al $6061 \mathrm{AlMg} 1 \mathrm{SiCu}$

Tabel 7. Distribusi besaran unsur lapisan diamond-film pada $\mathrm{V}=350 \mathrm{~m} / \mathrm{min}$

\begin{tabular}{|c|c|c|c|}
\hline Element & Weight \% & Atomic \% & Keterangan \\
\hline \multicolumn{4}{|c|}{ Spectrum-1 } \\
\hline $\begin{array}{l}\text { Carbon } \\
\text { Cobalt } \\
\text { Tungsten }\end{array}$ & $\begin{array}{l}99.113 \\
0.626 \\
0.260\end{array}$ & $\begin{array}{l}99.854 \\
0.129 \\
0.017\end{array}$ & $\begin{array}{l}\text { Unsur lapisan/pelapis } \\
\text { (diamond film) } \\
\text { signifikan }\end{array}$ \\
\hline \multicolumn{4}{|c|}{ Spectrum-2 } \\
\hline $\begin{array}{l}\text { Carbon } \\
\text { Tungsten }\end{array}$ & $\begin{array}{l}99.947 \\
0.260\end{array}$ & $\begin{array}{l}99.997 \\
0.003\end{array}$ & $\begin{array}{l}\text { Unsur lapisan/pelapis } \\
\text { (diamond film) } \\
\text { signifikan }\end{array}$ \\
\hline
\end{tabular}

Pada Gambar 22a . dan Tabel 7, pada spec-1, hasil dari analisa energy dispersive spectroscopy (EDS) didapati besar sebaran unsur pelapis/lapisan diamond-film (carbon) terdeteksi signifikan hingga mencapai 99.854, sehingga dapat diartikan bahwasanya pada daerah kritis terjadinya kegagalan pahat (abrasive-wear) yang terdeteksi diketahui adalah material unsur pelapis diamond-film yang masih berwujud keadaanya dan masih konsisten melapisi material substrate pahat.

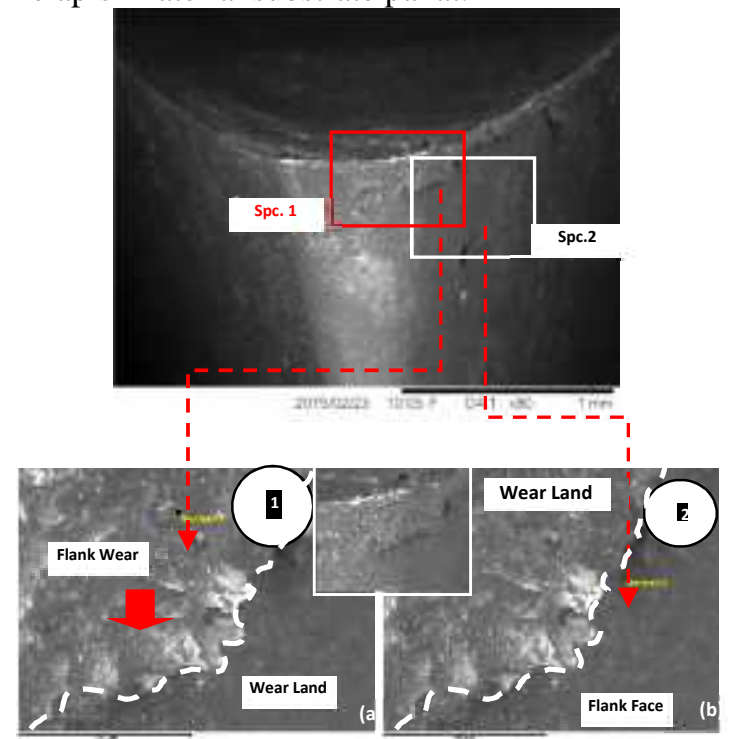

Gambar 22. Daerah analisa: [a] Spec -1; [b] Spec -2, Penyelidikan unsur lapisan pahat bahan uji Al-6061. Kondisi $\mathrm{V}=350 \mathrm{~m} / \mathrm{min} \mid \mathrm{f}=0.15$ $\mathrm{mm} / \mathrm{rad}|\mathrm{a}=1.5 \mathrm{~mm}| \mathrm{t}_{\mathrm{c}}=1.736 \mathrm{~min} ; 104.160$ $\mathrm{dtk} \mid \mathrm{V}_{\mathrm{B}}=0.070 \mathrm{~mm}$.

Sementara itu, Pada Gambar $22^{\mathrm{b}}$ dan Tabel 7. Spec-2, dapat diuraikan hasil dari analisa energy dispersive spectroscopy (EDS) menunjukkan besar sebaran unsur pelapis diamond-film (carbon) terdeteksi signifikan dan utuh hingga mencapai prosentase $99.997 \%$, sehingga dapat diartikan 
bahwasanya daerah analisa pada spec-2 adalah material unsur pelapis diamond-film sepenuhnya dan tidak terpengaruh oleh unsur-unsur lainnya yang merusak struktur lapisan dimond-film pahat.

\section{Kesimpulan}

Hasil penelitian yang diperoleh dari pengujian pada pendekatan pengaruh interaksi secara Kimiawi yang terjadi antara bahan benda kerja dan pahat merupakan jawaban dari tujuan khusus, dimana hasil analisa terhadap pengujian tersebut dapat disimpulkan sebagai berikut:

Karakteristik kegagalan pahat berupa pengelupasan pelapis/lapisan diamond-film pahat karbida berlapis tidak ditemukan pada operasi bubut kering bahan uji tingkat kekerasan 53.3 HRB. Kegagalan pahat yang terjadi ditemukan Aus pengikisan (abrasive-wear) sebesar $\mathrm{V}_{\mathrm{B}}=0.070 \mathrm{~mm}$. dengan percepatan Aus rata-rata $\mathrm{V}_{\mathrm{B}}{ }^{\circ}=0.000672$ $\mathrm{mm} / \mathrm{s}$.

\section{Pengujian pengaruh interaksi Kimiawi}

a. Hasil analisa distribusi besaran sebaran unsur pelapis (diamond-film) yang dianalisa pada spec-1 terdeteksi signifikan mencapai $99.854 \%$ dan pada spec-2 menunjukkan besaran sebaran unsur terdeteksi signifikan dan utuh hingga mencapai prosentase $99.997 \%$, Dikarenakan melalui hasil identifikasi distribusi unsur pada titik analisa pada spec-1 dan spec-2 diketahui adalah material unsur pelapis diamond-film yang masih berwujud utuh keadaanya dan masih konsisten melapisi material substrate, maka dismpulkan tidak adanya indikasi telah terjadi pengelupasan lapisan/pelapis pahat terhadap material substrate diamond-film pahat.

b. Hasil analisa mikrostruktur diinformasikan bahwa distribusi besaran sebaran unsur elemen pelapis (diamond-film) yang dianalisa pada spec-1, menunjukkan tidak terjadi kegagalan fungsi dari pelapis diamond-film. Hal ini dibuktikan melalui distribusi besaran unsur elemen pelapis yang dianalisa pada titik spec-1 yaitu unsur pelapis diamond-film terdeteksi signifikan $94.329 \%$ dan pada spec-2 $99.992 \%$. Dengan demikian hasil identifikasi distribusi unsur pada titik analisa spec-1 dan spec- 2 tidak terlihat adanya indikasi telah terjadi pengelupasan lapisan pahat terhadap material substrate, karena diketahui unsur yang terdeteksi adalah unsur material pelapis diamond-film masih berwujud.

c. Hasil pengujian menjelaskan bahwa distribusi unsur pelapis diamond-film pada spectrum-1 terdeteksi hanya pada besaran prosesntase $35.105 \%$ dan telah terjadi pengurangan volume unsur material tunggal pelapis diamond-film (carbon $100 \%$ ) hingga mancapai $64.895 \%$. Sementara itu, pada spectrum-2 didapati besar sebaran unsur pelapis diamond-film terdeteksi sangat signifikan $99.997 \%$. Maka jika diamati fonomena sebaran unsur yang terjadi pada spec1 dan spec-2 pada titik analisa disimpulkan tidak terjadi peristiwa pengelupasan lapisan (coating delamination) dimond-film pahat, melainkan telah terjadi Aus pengikisan lapisan (abrasive coating wear) dikarenakan prosentase jumlah unsur material pelapis diamond-film telah berkurang drastis hingga lebih dari $50 \%$ atau dengan kata lain keberadaan unsur lapisan/pelapis diamond-film pahat sudah tidak berwujud sempurna lagi. Peristiwa terjadinya Aus pengikisan lapisan (abrasive coating wear) pada kecepatan potong yang rendah (temperatur rendah) dikerenakan unsur material ferro $(\mathrm{Fe})$ belum bereaksi terhadap unsur substrate pahat (WC/Co) sehingga tidak menyebabkan reaksi kimia yang menghasilkan karbon, karena ferro (Fe) tidak akan bereaksi dengan lapisan diamond-film (carbon) pahat.

d. Hasil penelitian diinformasikan bahwasanya fonomena distribusi sebaran unsur yang terjadi pada daerah analisa spec-1 menjustifikasi sudah hilangnya sebahagian volume pelapis diamondfilm yang melapisi material substrate, dikarenakan keberadaan unsur lapisan diamondfilm (carbon) pahat sudah tidak berwujud sempurna yaitu dengan prosentase hanya sebesar $67.573 \%$. Sementara itu pada spec-2 didapati besar sebaran unsur pelapis diamondfilm (carbon) terdeteksi sangat signifikan hingga mencapai $95.698 \%$. Jika diamati fonomena sebaran unsur yang terjadi pada spectrum-1 dan spectrum-2 pada titik analisa disimpulkan juga tidak terjadi peristiwa pengelupasan lapisan/pelapis (coating delamination) dimond-film pahat, melainkan telah terjadi Aus pengikisan lapisan (abrasive coating wear) dikarenakan prosentase jumlah unsur material pelapis diamond-film telah berkurang hingga lebih dari $30 \%$, dengan kata lain keberadaan unsur lapisan/pelapis diamondfilm pahat sudah tidak berwujud sempurna lagi. Sebab terjadinya peristiwa Aus pengikisan lapisan (abrasive coating wear) pada peningkatan kecepatan potong (temperatur tinggi), adalah pengaruh unsur material ferro (Fe) akan bereaksi terhadap unsur substrate pahat (WC/Co) sehingga dimungkinkan menyebabkan reaksi kimia yang menghasilkan karbon hasil pembakaran (thermal), karena ferro (Fe) akan bereaksi dengan unsur Tungsten (WC) dan unsur Cobalt (Co) material substrate pada temperatur tinggi. 


\section{Daftar Pustaka}

[1] Jhon A.Schey, 2009, Proses Manufaktur "Introduction to Manufaktur Processes" Edisi ketiga".

[2] Armansyah Ginting, 2004, Analisa Pembentukan Serpihan Tehadap Kegagalan dan Mekanisme Aus Pahat Karbida pada pembubutan kering Aluminium 6061-T6.

[3] Sreejith, and Ngoi, B.K.A., 2000, Dry machining, machining of the future. $\mathrm{J}$.

[4] Schulz, E. Abele, A. Sahm, 2001, Material aspects of chip formation in HSC machining, Ann. CIRP 50 (1) 45-48.

[5] M. Fitzsimmons, V.K. Sarin, 2001, Surf. Coat. Technol, 158.

[6] M. Nouari, A. Ginting, 2006, Wear characteristics and performance of multilayerCVD-coated alloyed carbide tool in dry end milling of titanium alloy.

[7] J. Hu a, Y.K. Chou, R.G. Thompson, 2008, Nanocrystalline diamond coating tools for machining high strength Al alloys.

[8] Armansyah Ginting, 2003, High Speed Machining of AISI 01 Steel With Multilayer Ceramic CVD-Coated carbide; Tool Life and Surface Integrity, Vol 14, No. 3, Agustusmajalah IPTEK.

[9] Seco. Dry Machining, (2004).

[10] Abdeel-Aal, H.M., Nouari, M., El-Mansori, M. and Ginting, A. 2006. Conceptual triboenergetic analysis of cutting tool protective coating delamination in dry cutting of hard-tocut engine alloys. Submitted to Int. J. Adv. Manuf. Technol.

[11] U.Prabhu Arumugam, Ajay P Malshe, Stephen A Batzer, Deepak G Bhat Study of Airbone Dust Emissionand Orocess Performance During Dry Machining of Aluminum-Silicon Alloy with PCD and CVD

[12] Boothroyd, G., 1975, "Fundamentals of Metal Machining and Machine Tools, International Student Edition", McGraw-Hill, Tokyo, Japan.

[13] Rochim T. Teori dan teknologi permesinan, HEDS, (1993)

[14] ISO 3685, "Tool-life testing with single-point turning tools",1993.

[15] Kalpakjian, S.,"Manufacturing processes for engineering materials", Wesley Publishing Company, USA, (2003).

[16] Sandvik Coromant, 2012, General Catalogue, (2012)., Enginering Steel.
[17] Apri Nuryanto \& Sutopo, 2006, Pengaruh variasi kecepatan potong, feeding dan Kedalaman potong terhadap umur pahat hss yang dilapis aln-tin-aln.

[18] Manage, D.P., 1998, Structural and Optical Characterization of Hydrogen Amorphous Carbon Thin Films. University of Toronto: Ph.D Thesis. 